\title{
An International Approach to Speechwriting and Speechwriters: A Qualitative Study
}

\section{Konuşma Metni Yazımı ve Konuşma Metni Yazarlarına Yönelik Uluslararası Yaklaşım: Nitel Bir Çalışma}

\section{Öznur YÜKSEK VERGIVEREN ${ }^{1}$ [}

'Lecturer, Ph.D. Candidate, Selçuk University, Faculty of Communication, Department of Public Relations, Konya, Turkey

ORCID: Ö.Y.V. 0000-0002-1439-2231

Corresponding author:

Öznur Yüksek Vergiveren, Selçuk Üniversitesi,

Illetişim Fakültesi, Konya, Türkiye

E-posta/E-mail:

yuksekoznur@gmail.com

Received: 21.10 .2020

Revision Requested: 24.12.2020

Last revision received: 28.05 .2021

Accepted: 25.01 .2021

Citation:Yüksek-Vergiveren, Ö. (2021). An international approach to speechwriting and speechwriters: A qualitative study. Connectist: Istanbul University Journal of Communication Sciences, 61, xx-xxx.

https://doi.org/10.26650/CONNECTIST2021-0126

\begin{abstract}
Today, public speeches have a broader importance than they had before, since the transmission of a message/event has sped up significantly due to internet-based communication tools. When the role of speeches for individuals, organizations, societies, and countries is considered, designing a speech becomes more crucial. In addition, speeches feature in building the character of a company, a political party, or a person. In this context, while the number of speechwriters has increased noticeably, the profession in the communication realm is still highly invisible and, as a result, academic research on the subject is limited both in Turkey and beyond. This study aims to draw attention to speechwriting based on ancient rhetoric and to expose a broad international perspective on it. To reveal differences in implementation and perception and to find common ground in speechwriting, structured, in-depth interviews with twenty prominent speechwriters serving in the public and private sectors in ten different countries were conducted. According to the analysis, the international perspectives can be categorized regarding the length of a speech (15-20 minutes), the steps of speechwriting (research, imagination, mind mapping, determining the main message and side elements, writing the first draft, revising the text based on feedback), audience analysis, the structure of sentences (short and active sentences blended with long ones), and speechwriters' characteristics (language skills, modesty, patience, etc.).
\end{abstract} Keywords: Public relations, rhetoric, speechwriting, speechwriter, speech

ÖZ

Internet tabanlı iletişim araçlarının etkisiyle bir mesajın/hadisenin kolaylıkla yayılabildiği günümüzde, halka açık konuşmalar eskisinden çok daha önemli bir hal almıştır. Konuşmaların bireyler, kuruluşlar, toplumlar ve ülkeler üzerindeki rolü düşünüldüğünde, bir konuşmanın tasarlanması, gerekliliğin ötesine geçmiştir. Ayrıca konuşmalar, bir şirketin, siyasi partinin veya kişinin karakter inşasında önemli bir etkiye sahiptir. Bu bağlamda, konuşma metni yazarlarının sayısı fark edilir şekilde artarken, iletişim alanında bir uzmanlık dalı olarak neredeyse görünmez durumdadır ve bunun sonucu olarak hem Türkiye'de hem de dünyanın geri kalanında akademik alanda konu üzerine araştırmalar sınırlı 
sayıdadır. Bu çalışma, kadim retorik disiplinine dayanan konuşma metni yazımına dikkat çekmeyi ve uluslararası bir perspektif ortaya koymayı amaçlamaktadır. Konuşma metni yazımı konusunda uygulamadaki ve algıdaki farklılıkları ve ortak noktaları ortaya koymak için on farklı ülkeden hem kamu hem de özel sektörde görev yapan önde gelen yirmi konuşma yazarı ile yapılandırıımış derinlemesine görüşmeler yapılmıştır. Yapılan analize göre, uluslararası ortak düşüncenin oluştuğu konular, konuşmanın uzunluğu
(15-20 dakika), konuşma metni yazım aşamaları (araştırma, tasavvur, zihin haritalama, ana mesajın ve yan unsurların belirlenmesi, ilk taslağın yazılması, geri bildirimler çerçevesinde metni revize etme), izleyici analizi, cümlelerin yapısı (uzun cümlelerle harmanlanmış kısa ve aktif cümleler) ve konuşma yazarlarının özellikleri (dil becerileri, alçakgönüllülük, sabır vb.) şeklinde gerçeklemiştir.

Anahtar Kelimeler: Halkla ilişkiler, retorik, konuşma metni yazımı, konuşma metni yazarı, konuşma

\section{INTRODUCTION}

Speechwriting, based on ancient rhetoric, has recently been recognized as a profession again. Despite massive advances in communication technologies in the last three decades, as a unique component, the message spares its importance by being the backbone of communication. It must be pointed out that professional design of a message becomes a necessity due to the sharp rise in the number of messages and sources. As a vital method of message transmission, public speeches should be organized meticulously, keeping in mind the advantage of face-to-face communication and live performance opportunities via broadcast.

The importance of a speech in politics is obvious, but at the same time public speeches determine the line between success and failure in many areas of life, like business and the arts. Richard Branson, Steve Jobs, and Annita Roddick, all three of whom consciously used speeches to reflect their personalities in their companies, turned their companies into powerful brands Virgin, Apple, and the Body Shop (Lancaster, 2010, p. 17). Thus, the analysis of speechwriting in this research is not just limited to politics, but instead, it is designed to cover all possible speeches written for leaders in various areas.

Public speech texts are written locally, nationally, or internationally for influential persons, leaders, or politicians in both the political arena and non-governmental organizations like the private sector and non-profit organizations. Speeches that address the masses are always significant when their relations to the past, present, and future are considered. They are helpful texts for evaluating or understanding the past and for 
being the knots they are in the braid of history. Their relation to the present involves their influence on the current political, economic, and sociological events of communities. Their relation to the future is generated by their effect on the relationships among persons, institutions, and countries for future generations. In this context, the subject of this study is composed of the construction of these speeches, the importance of which is briefly mentioned above. The construction of a speech includes many stages, such as research, design of the information, emotional touches, wording, and revising. In addition, the speechwriter-speaker relationship, the ambiance of the venue, the target audience, whether it is to be broadcast or not, should all be evaluated in the process to craft an appropriate speech.

In light of the information, the aim of the study is to identify the common points and divergences in speechwriting practice and also to underline the specific characteristics of a speechwriter, describe the speechwriter-speaker relationship, discuss the effect of the media on speeches and unveil whether speechwriter is used as a title without hesitation by these professionals.

To gather information on speechwriting and reveal an international perspective, in-depth interviews were conducted with twenty speechwriters who write for renowned and important institutions and speakers. The interviews were performed in Canada, Denmark, Germany, Holland, Nigeria, Scotland, Tanzania, Turkey, the United Kingdom (UK), and the United States of America (USA). Europe and the USA seem to be central to speechwriters' networks, as both countries host most of the organizations for the profession.

Prominent books on public speaking or speechwriting have been written by Burgoon (1974), Collins (2005), Coombs (2009), Glover (2011), Kjeldsen et. al. (2019), Lancaster (2010), Leith (2011) Luntz (2007), Medhurst (2003), Meyer (2009), (Muallimoğlu (2011), Osborn and Osborn (2000). Kjeldsen et. al. $(2019$, p. 39) underlines that it is possible to find out a high number of researches on political communication and some on political speechmaking whereas speechwriting studies are limited. This study may add value to the literature when the limited attention to the profession and limited academic study in Turkey and the world are considered. Contributions to literature and practice enlightening the main subjects of speechwriting, particularly its boundaries, methods, and processes are also necessary for future studies. 


\section{The Importance of Text Authorship in Public Relations}

Words or messages form the basis of communication. Improvements in communication methods and their evolution into two-way and instant interactions are highly striking innovations in the area of communication. The only thing that has not changed throughout the history of humanity is the message. Steward $(2005$, p. 41) explains the importance of writing as follows: In this era of visual communication, many believe that writing has become old-fashioned. Those who do not appreciate how fundamental the written word is for communication should think about the Bible and the Qur'an. The messages of these two books have created massive effects on people's lives for the last two thousand years.

Either in written or visual form, there is no doubt that a conveyed message has always existed. Nowadays, there is a virtual world, which turns every individual into a separate information source. In this world, the successful transmission of the message to the recipient depends on catching their attention instantly, hence the need for a message with a special goal and design rather than a random flow of messages. All these developments render the writing and writers of public relations texts more important.

In fact, text authorship in public relations is an effective tool if it gives versatile information to the customers and the community. The text should include contents oriented to the product, the administration, the methods used, and the society. If the texts are planned in a perfunctory and shallow way with a self-seeking business mentality, they will have a negative effect instead of supporting the organization. In institutional magazines, brochures, correspondence or commercial texts, which will show up in the media, brief, clear, strong, and sincere content should be formed with care. The community seeks such answers to questions such as how the organization treats its employees, whether it provides scholarships for their education, what kind of roles it takes up in the society, if it opens its facilities to public access, or if it contributes to community projects (Morton, 1968, p.33).

From this point forth, the importance of text authorship in public relations comes to light. To develop common understanding in the communication of an organization with its public, a text should be written with appropriate language and wording for the audience as well as including all the information that needs to be known. Newsom 
and Haynes (2008, p. 3) explain the requirements as follows: "Good public relations requires communication skills, expertise in dealing with news media and knowledge of mass communication, the dynamics of public opinion and the principles of persuasion."

After having touched upon the importance of text authorship in public relations, elaboration on speechwriting will be useful. Rhetoricians emphasize the fact that since Abraham Lincoln, no presidents or political figures whatsoever have written their own speeches. Abraham Lincoln wrote the Gettysburg Address while he was on a train going from Washington to Gettysburg, and this speech is regarded as a very good text by many leading experts in the area (Bivins, 1999, p. 45). It is not considered possible for either political figures or directors in other areas to write their own speeches due to time restrictions in this century which demand that speed in communication comes to the forefront. For this reason, obtaining professional services from speechwriters becomes mandatory for many people, institutions, and establishments. In this section, brief information about rhetoric, which forms the basis of this topic, will be given before evaluating the speech writing process.

\section{Aristotle's Rhetoric}

When it comes to rhetoric and speechwriting, many authors take Aristotle as a reference and use his ideas and techniques as a basis. For instance, in his book Speechwriting, Lancaster (2010, p. 22) describes Aristotle's The Art of Rhetoric, written in 350 B.C. as "the first definitive account of the art of speechwriting". Booth (2004, p. 3) also describes this as the first notable and far-reaching book in the area. Tepebaşılı (2016, p. 19), who claims that there is more than one rhetorical system, asserts that apart from a few contributing names, the system was mainly developed by Aristotle, Cicero, and Quintilian, but he also emphasizes that there is no fixed system.

On the other hand, Meyer (2009, pp. 9-10) reviewed the definitions of rhetoric throughout history in three categories: 1 . Rhetoric is the manipulation of the audience (Plato), 2. Rhetoric is the art of fine speech (Quntilianus), 3. Rhetoric is the display of arguments and discourses that must or aim to persuade (Aristotle). Meyer evaluated the divergence points of these definitions, in other words, the differences in the points of emphasis. Accordingly, the role of the listener is prioritized in the first definition, the value of the orator in the second, and the weight of thoughts and language in the third definition, which attributes rhetoric a more objective and rational appearance. 
According to Aristotle, rhetoric is "the faculty of observing in any given case the available means of persuasion" (Aristoteles, 2014, p. 37). Thus, unlike other branches of art, rhetoric does not have a particular or absolute classification (Aristoteles, 2014, p. 37). Aristotle's understanding of rhetoric involves three types of persuasion methods: ethos, pathos, and logos. In other words, they are character, emotion, and demonstration (Aristotle, 2004, p. 110). Ethos (the credibility of the speaker) depends on the personality of the speaker and is defined as the persuasion realized by forming a convincing image of the speaker. Aristotle stated that decent people are more credible than others (Aristoteles, 2014, p. 38). According to Greeks, ethos is the image of self, character, personality, behaviour, life, and objective preferences (thus ethics) (Meyer, 2009, p. 25). The features, which provide authority to the speaker, are a decent and good attitude, virtue, trust, and reassurance (Meyer, 2009, p. 26). Pathos (understanding the audience and addressing the emotions) is based on putting the audience into a certain mood, and persuasion fulfilled through the audience by awakening the emotions (Aristoteles, 2014, p. 38). Concerning the principal aims to inflict a certain mood on the audience, Lukaszewski $(1992$, p. 11) indicates that people do not become interested in facts or data unless their mood is affected. People pay attention to their own feelings and values and want to know how the decision of the speaker will influence their health, security, personal assets, and place in society, inner peace, and economic safety. Therefore, many speakers use opposing emotions such as hope and fear, rage and mercy, and shame and pride (Lancaster, 2010, pp. 115-116). The top ten emotions frequently used in speeches are listed as follows: the positive ones are calm, friendship, favour, and pity, and the negative ones are anger, fear, shame, indignation, envy, and jealousy (Aristotle, 2004, p. 221). Logos (logic) defines the situation in which persuasion takes place on its own when a fact or so-called fact is proven by appropriate evidence (Aristoteles, 2014, p. 38). Logos is both practically and ethically crucial in a speech and proves that the issue in question is more than an imaginary state in the speaker's mind. For this reason, the facts are based on statistics and proof, and the process goes as follows: Firstly, an assertion is brought forward to be proven, then the supporting evidence is presented, and finally, the relationship between the assertion and the evidence is revealed (Osborn \& Osborn, 2000, pp. 393-394).

Meyer (2009, p. 41) mentions three big moments of rhetoric from the prologue to the conclusion. According to this, ethos addresses the audience and aims to attract attention. Afterward, logos is used to either support or oppose the idea. The speaker ends the presentation with pathos, as now it is required to address hearts of the listeners 
and their emotions. Aristotle not only indicated that these three elements are equally important and complementary in any convincing speech but also claimed that they support the speech in collaboration (Lancaster, 2010, p. 22). In light of this information regarding rhetoric, it will be appropriate to feature the parts of a speech text, the qualities of these parts, and the stages of text writing.

\section{Parts of The Speech}

Determining the parts of the speech also shows what a speech should include. The classical classification of introduction (exordium), narrative (narratio), argumentation (argumentatio) and conclusion (peroratio) is a significant and commonly used fragmentation method. While the prologue and the conclusion, which address the emotions of the audience and targets, remain in the outer frame, the narrative and argumentation constitute the inner frame as the main part where the speaker demonstrates his/her skills of logic using evidence and presentation (Tepebaşılı, 2016, p. 48).

The pentad used by Greeks and Romans is, on the other hand, presented as follows:

Prologue: attracts the audience's attention.

Narrative: introduces the major content and builds the case.

Proofs: presents arguments supporting the speaker's content.

Refutation: refutes counter-arguments.

Conclusion: Summarizes, reviews the main points, and ends the speech (Glover, 2011, p. 189).

When writing a speech, three principles should be taken into consideration. The first is simplicity, which is fundamental for the audience to follow and understand the speaker and remember the message. The second is balance, where the duration allotted to the introduction, body and conclusion sections should be well distributed. The introduction and conclusion should take an equal amount of time, whereas the body should be the longest. The third principle is order, the appropriate development of the speech from the beginning to the end, making the introduction, explaining the main ideas in the body, and finishing with the conclusion (Osborn \& Osborn, 2000, pp. 190-193). 
The introduction/beginning of the speech is important to attract the attention of the audience. Moreover, this is not only the part where the speaker prepares the whole background of the speech but also where the audience decides if they are going to like or become interested in the speaker (Collins, 2005, p. 38). Bivins (1999, p. 238) indicates that when starting the speech, the speaker should explain why the audience should listen to him/her, establish a bond by referring to their common points, and give a short summary of what they are about to hear to attract their attention. In the body of the speech, the main points should be arranged in a logical sequence and supporting elements should be used for each point. Leith $(2011$, p. 81$)$ says that after finding the subject and discovering the evidence, the existing material should be arranged in order and that the best way to do this is to conclude by emphasising the strongest arguments and minimalizing the weakest ones. The significance of the introduction was mentioned before, but the conclusion is in many ways more important than the introduction. Even if the speaker makes an exceptional start and keeps interest alive throughout the speech, a weak conclusion/epilogue may cause all the success to go down the drain (Collins, 2005, p. 41). The key points should be arranged in the conclusion, and the speech should end with a remarkable expression so that the audience is left in a certain mood; lastly, if appropriate, the audience should be called to take action (Bivins, 1999, p. 238). Bradley (1975, pp. 124-131) states that there are many ways to end a speech. According to this, one of the easiest and effective ways to end a speech is by giving an abstract of the whole, which facilitates recall through repetition, an essential component of rhetoric. In addition, the main message or central point can be reinforced by quoting an authority who is familiar to and highly respected by the audience. Another method is to make a call for action for the desired event to take place. In addition to this call for action, one of the most used methods is to ask the audience for a mental or emotional commitment. Finally, illustrations and humour can be used to close the speech.

\section{The Stages of Speechwriting}

Although there are divergences when it comes to the production stages of a speech, a pentad of steps, appreciated by Lausberg, Ueding or Fuhrmann, is widely accepted. These five steps are as follows: 1. Finding, 2. Arranging, 3. Wording, 4. Memorizing, and 5. Presentation and body language. These steps are divided into two groups: while the first two steps are part of the "thinking stage", the last three are included in the "language stage" (Tepebaşıll, 2016, p. 26). This system, which can be defined as the speech 
production stages, also includes the moment where the speech takes place. Excluding the speech itself, the part concerning the speechwriter can again be classified into five stages (Muallimoğlu, 2011, p. 35): 1. Choosing the subject, 2. Finding and arranging the necessary material, 3 . Choosing the ideas that will be used to support the main point of the speech, 4. Preparing the plan of the speech, and 5. Oral rehearsals.

The first step of writing a speech text is choosing a special topic according to the speaker, the audience, and the situation. It is necessary to find a focus point and draw the boundaries of the subject, for in speeches, it is required to reach an objective in a restricted period of time. After determining the topic, the speechwriters must collect and arrange the information and documents that they need. These include supporting statistical data, the views of experts or respected authorities on the issue; evidence and testimonies, examples to illustrate the topic; and stories to render the subject more interesting and convincing (Osborn \& Osborn, 2000, pp. 34-36). Lancaster (2010, p. 53) does not only talk about the research of the subject but also adds the research of the speaker in the preparation process, too. He also thinks the most important point to understand one's style is not listening to what is said but how it is expressed. Another crucial point is to reveal the relationship between the speaker and the topic. It should be questioned if a message related to a topic is new or mentioned in previous speeches as a message building process (Kjeldsen et. al., 2019, p. 188).

Furthermore, Burgoon (1974, pp. 242-245) asserts that those factors the speaker cannot control should be analysed, such as the place where the speech will be given and characteristics of the environment, the time of the speech, and the order of the speech and the event. While some venues directly affect the content and style of a speech, such factors as sound, light, and temperature play a role in its efficiency. Also, if there is more than one speaker, time restrictions may be applied.

As described above, after all the preparations are completed, the speech plan is made, and the main thesis is decided. Then, the process continues with speechwriting and revision of the text with feedback from the speaker.

In this context, Wallace (2020, p. 209) mentions that speechwriters' degrees of control over the final speech could be changed due to relationships between speechwritersspeakers and adds "The closer a speechwriter is to her principal, the more power she has in her pen and the greater ethical responsibilities are likely to be". 


\section{AIM AND METHODOLOGY}

Speechwriting as a profession has become relatively visible in recent decades in the international communication realm whereas studies and research on the subject are still rare. This study firstly aims to draw an international perspective on speechwriting practices through twenty in-depth interviews with speechwriters from ten countries. The second aim of the research is to contribute to create awareness of the profession.

\section{Aim}

The study aims to present an international perspective on speechwriting and to reveal common points and divergences in practice. Very limited research has been conducted in the realm of speechwriting in Turkey and many other countries. In addition, existing studies, where academic studies in this field predominantly manifest themselves, include the design of a speech in regard to the country-specific culture and traditions. Therefore, in-depth interviews with twenty experienced speechwriters in ten countries (America, Canada, Denmark, England, Germany, Nigeria, the Netherlands, Scotland, Tanzania, and Turkey) were conducted and the results were evaluated. This study is based on the elaboration of the steps from the moment of realization that the speech is needed to the process of speechwriting, its presentation, and its place in traditional and social media. In this context, answers to four main questions about speechwriting were sought:

1) What qualifications should a speechwriter have?

2) What are the stages of speechwriting, and what is the process?

3) What is/should be the relationship between the speechwriter and the speaker?

4) What are the techniques for making a speech in traditional media, and how does social media affect speeches?

\section{Methodology}

In this research, a qualitative research technique (structured in-depth interviews) was used and interviews were conducted with twenty speechwriters from ten different countries over approximately one year, between April 2015 and May 2016. The in-depth interview is an information-gathering technique which spans all aspects of the subject by asking mostly open-ended questions and aims to obtain detailed answers while 
giving the researcher the opportunity to obtain information piece by piece. Emotions, information, practice, and observations of the person interviewed are accessed through the dialogue (Tekin, 2012, p. 101). In-depth interviews are generally classified into three types: structured, semi-structured, and unstructured interviews. Structured interviews are conducted using questions written by the researcher. In semi-structured interviews, the main questions are developed in advance, but when needed, new questions can be directed to the interviewees. In an unstructured interview, the researcher starts with an initial question while being aware of the subject and aims to obtain detailed information from conversation (Erdoğan, 2012, pp. 220-221). The primary reason for applying the structured in-depth method in this study is that most of the interviews were conducted via e-mail due to geographical distances, and this method allows the researcher to group the subjects within specific topics. Considering their methods, interviews are divided into two categories: text-based and voice-based. In text-based interviews, letters, e-mail, and web dialogues can be used (Geray, 2006, pp. 166-167). Thanks to Internet technologies, in-depth interviews are commonly performed via e-mail. Meho (2006, p. 1285) emphasizes that this inexpensive method is beneficial, especially for people who prefer this method instead of face-to-face conversations and those who are too far to be able to conduct interviews in person.

When determining the research sample, maximum variation sampling was primarily used as a type of targeted sampling method. Rather small sampling groups can be focused on in qualitative-based research. Sometimes, the sample can even be only one person (Patton, 2002, p. 230). In qualitative research, the targeted-sample method is used to choose appropriate and effective participants. In the maximum variation approach, the researcher analyses a potential sample group which includes the maximum variation of places and people (Seidman, 2006, pp. 52-53). In this context, the participants for this study and their career history can be seen in Table 1. Data obtained from the research were interpreted using the descriptive analysis method, in which data are summarized and interpreted according to certain themes.

\section{FINDINGS}

In this study, speechwriting is evaluated according to four different categories related to the questions mentioned in the aim: (1) Qualities of speechwriters, (2) the speechwriting process, (3) the speechwriter-speaker relationship, (4) the appearance of speeches in traditional media, and the effect of social media on speeches. 


\section{Qualities of The Speechwriter}

Firstly, among the university majors that speechwriters studied, Language and Literature is at the top of the list among the research sample. In this regard, five speechwriters studied language and literature, three of them in English, one in Urdu, and the other in German and French. Three of the participants had training and graduated from university with degrees in political sciences, three in communications, two in law, two in history, one in international relations, one in philosophy, one in both philosophy and international relations, and one in cultural anthropology. Only one participant had not graduated from university and trained himself in journalism. Nine out of twenty participants who took part in the research had either attended short-term courses in addition to their studies or had taken postgraduate education. To give an example, a participant who was trained in English language and literature continued with courses on communication and PR afterward. A speechwriter who completed history training then took literature and political sciences courses. One can understand from these examples that the speechwriters enriched their conceptual knowledge, data resources, and abilities by continuing their education in various fields. In speechwriting, to meet the expectations of in-depth vision not only in proficiency in language but also in many fields like politics, culture, and history, participants' educational background is meaningful.

When it comes to must-have qualities of a speechwriter, it can be easily seen that nearly all participants possess strong language skills. Their writing is not limited only to speechwriting, but they also stay in touch with the masses through books, columns, and scripts. When their previous experiences are considered, participants' contributions to intellectual production can be seen clearly since ten participants have worked in either journalism, PR, corporate communications, or script and book writing. Other participants took part in the political consulting. Only two participants made their careers directly in speechwriting. According to the thirteen different participants, the main qualities of a speechwriter are proficiency and mastery of language, the skill of simplifying complex topics, the ability to empathize, creativity, intelligence, curiosity, interest in current events, and knowledge of general culture. According to characteristic features, modesty and patience stand out among the others.

Participants were asked whether they use speechwriter as a title to understand the place of the job in terms of general acceptance and institutionalization. The participants answered this question in two different ways, their own opinion and in general terms. 
Seven participants said they use the title, six expressed that they prefer using different titles like text writer, political consultant, media consultant, and communication expert. Six participants said they use both speechwriter and other titles according to the situation at hand. Only one participant expressed that a speechwriter should be invisible. The important point to be focused on here is only seven participants expressing that they can comfortably use the title. The second important point is why they do not prefer to use speechwriter as a title. Having wider roles in communication, the limitations of the audience's knowledge about the prevalence of this type of work, and restrictions from their superiors or the speaker(s) they serve are among the main reasons for this hesitation.

\section{The Speechwriting Process}

Before the questions about speechwriting, participants were asked whether they work alone or with a team. Eight participants expressed that they work on their own, seven said they work with a team, three said they do both, and two said they work partially with a team. The ones who said they work with a team said that this team mostly supports them in obtaining data and the editing process, and they generally write the final text themselves.

When it comes to the context and design of the speech texts, it is understood that obtaining data and detecting the features of the audience are vital. All the participants answered the question of whether they take the audience into account positively to different extents (in-depth/partially/slightly), and added that they research the subject and the event. It becomes clear according to the data gathered from participants that a solid analysis must lead the research to construct logic and emotion properly. Then, these data should be edited, linked to each other, and processed through mind mapping. Stories, personal touches, and emotions add new levels and raise the spirit of the text on this basis supported by evidence, statistical data, and examples. According to participants' answers, it is possible to summarize the steps of speechwriting as: research, imagination and mind mapping, determining the main message and side elements, writing the first draft, and revising the text with feedback.

Here, the need arose for evaluating the characteristic features of the introduction, body, and conclusion sections of a speech. Some of the participants answered this question by saying they do not obey exact rules, some mentioned their opinions about the whole text instead of separate parts, and others choose to give only hints about 
the rules they follow. From the terms the participants used, it is possible to understand that, because it provides the first impression of the speaker, the introduction must be short, effective, and alluring. The development is the part of the speech where the main points and arguments are developed around the key message, and it is enriched by descriptions, examples, statistics, and stories appealing both to emotions and logic. The conclusion must either call for action or provoke thought and should be as interesting as possible.

When asked about the important points of the execution of persuasion, participants provided different answers. These points are as follows: simple reporting sentences, clear sentences, logic, empathy, persuasive comparisons, personal connections, sincerity, stories, emotions, forming connections through the emotions of persons about a subject, data, an approach based upon statistics and sample events, perceptions and reflections of the speaker on the community, the credibility of the speaker, making the audience feel that upcoming action is the right thing to do and presenting logical arguments to make others believe, emphasizing the main point both in the beginning and at the end of the speech to make people see it, checking whatever was said before on the issue, a text fitting the speaker's character and wording, sharp statements, honesty, plain ideas, clarity, combination of logic + evidence + metaphor + story, a connection with the audience, plain and logical argumentation blended with inspirational pictures and emotions. It is observed again that the participants have different opinions on ethos, pathos, and logos, which are the three main persuasion methods of Aristotle. On this matter seven participants said ethos is the most important one, seven said all three are equally important, five said pathos is the most important, and one expressed that this kind of separation would not be right.

Regarding the rhetorical devices commonly used in speechwriting, certain techniques were identified, but some participants said they use all those devices, avoiding identifying one certain technique. Eight participants mentioned the rule of three, seven repetition, and six metaphor. In addition, four identified story/personal story and three rhetorical questions.

The structure of the sentence during text development is another point that needs to be highlighted. The participants emphasized using short sentences and avoiding passive voice. However, it became clear that the harmony of the text is as important as its intelligibility, and to achieve that, sentences of different lengths are needed. 
As far as the appropriate length of a speech derived from all these works, fifteen participants mentioned a duration of about 15-20 minutes, and all but one of them found a common foundation by emphasizing the importance of short speeches. In regard to the duration of the speechwriting process, there was a wide variation of responses from a few hours to a few weeks. Of course, what needs to be noted is that the duration depends on the writer's mood, workload, the type of speech, the subject, the contents of the speech, the availability of data, the need for a background search, the importance of the subject, the number of times the text is revised, the speaker, the time given to the speaker/length of the speech, the points that the speaker wants to address, the deadline, and bureaucratic issues.

\section{The Speechwriter-Speaker Relationship}

The speechwriter-speaker relationship is another influential and sensitive matter in speechwriting. This is because recognizing the person they will write for and understanding their expectations, whether they are verbalized or not, is important for the writer to internalize the text and reflect the speaker's own soul to the audience. The participants evaluated their relationships with speakers in three categories: business/ professionalism, sincere/warm, or variable. Considering different thoughts and experiences, it is possible to say that the speechwriter-speaker relationship depends on many factors. Because of this, it does not seem to be possible to present one as ideal or prioritize it amongst the given understandings. At this point, it seems necessary to ponder the possible prospect in case of a conflict between the speaker and the writer. Different opinions were given in this regard; for example, the speechwriter should think like the speaker, taking the matter into hand professionally without giving rise to that kind of situation. Otherwise, finding common ground and working properly is not possible under these circumstances.

\section{The Appearance of Speeches in Traditional Media and the Effect of Social Media on Speeches}

It would not be wrong to say that the primary goal of speeches is to influence the masses through face-to-face communication. However, when speeches, their scope, and the duration of their effects are considered, they also have the power to reach wider audiences through the media and to be timeless. Speeches that have taken place in history can still reach large audiences today and can penetrate people's inner worlds 
with their content. On this point, the speechwriters were asked whether they had various strategies or methods to make speeches appear in the media and to reach a wider audience. To this question, four participants said that this is outside of the context of their work, yet others mentioned some techniques. Foremost among these techniques was including short, effective, and impressive statements within the speech. Considering all the points mentioned by the participants in terms of media approval, the importance of short and striking statements, sound bites, and famous quotes as well as the value of interesting, surprising, controversial, and contrary ideas in a speech is understood.

To appear in the media, an effective method for speechwriters is to create text under the guidance of their own experiences, and the evaluation of the process together with the speakers and their advisors stands out as another way. In addition, it should be conveyed as another point of view that media coverage of the speech should be carried out by PR/media relations departments. For this reason, it is understood that it is not possible to draw a road map determined with certain borders so that the speech will be covered in the media.

Social media has become established in the current century as an innovation that affects not only speech texts but all areas of communication. For this reason, it was necessary to ask the participants whether this powerful area, where everyone can share their opinions and become famous even for a day, is an advantage or a threat to speeches. To the question regarding whether new media platforms are an advantage or not, more than half of the participants answered saying it is an advantage since it allows the speech to reach a wide audience within a short period of time. However, there was also some criticism saying no other platform can take the place of a live speech, and mistakes will spread at the same speed.

\section{DISCUSSION AND CONCLUSION}

While rhetoric has been a crucial matter in the communication realm since the ancient age, today, speechwriting becomes crucial in the area. Speechwriting, with its deep roots in rhetoric, has many areas of use, not just in politics but also the private sector, NGOs, governmental institutions, establishments, and so on. The main reason for needing a speechwriter can be described with the growing speed of technologybased communication and the leaders'/speakers' lack of time. Moreover, the number of messages reaching the masses increases constantly due to diversified communication 
tools. As a result, catching the public's attention and making them comprehend the message is directly related to the design of the speech.

In this context, despite the increasing demand for speechwriters and speechwriting, the critical point underlined here is that the profession is not sufficiently visible. This study has shown that most of the speechwriters hesitate to use speechwriter as a title, and only seven participants stated that they can comfortably use it. The reasons for not using speechwriter as a title can be summarized as the broader roles of speechwriters in the field of communication, the audience's limited knowledge about the prevalence of this type of work, and restrictions from the supervisors/speakers they serve.

As one of the main questions of the research is to analyse the critical qualities of a speechwriter, it can be easily seen that participants possess strong language skills and have an intellectual world expressing themselves through books, scripts, columns, TV production, and so on. Among others, modesty and patience are prominent characteristics of a speechwriter since writing speeches for the masses is a long and difficult process.

The second research question is about speechwriting rules and procedures from an international perspective. First, it is not possible to come up with a certain body of rules and draw a specific pathway for speechwriting. In the light of data obtained from the participants, perspectives are varied, and, at the same time, there are some issues most of them agree upon. As participants said, as in the art and music fields, it is not possible to sum up the speechwriting process in a set of rules. The speechwriter should have a good grasp of the culture, traditions, and worldview of the society they live in; design the speech by addressing both emotions and logic evenly; and shape the speech by considering the characteristics of the speaker. This is because speeches not only include thoughts, knowledge, or a thesis but also to contain a soul, touching the emotions. Of course, it should not be ignored that there are some techniques to take into account while forming a text that will impress the masses, evoke decision-making mechanisms, give rise to thinking processes or provoke certain emotions in the audience. The most frequently mentioned rhetorical devices among participants were, respectively, the rule of three, repetition, metaphor, the story/personal story, and the rhetorical question.

In the light of the responses, the steps of speechwriting can be described as follows: research, imagination and mind mapping, determining the main message and side elements, writing the first draft, and revising the text based on feedback. All the 
participants stated that the analysis of the audience is an essential practice in the speechwriting process along with research on the subject and event. Van Dijk (2008, p. 83) underlines the importance of having knowledge or beliefs about recipients in terms of speaking or writing appropriately. Furthermore, he points out the difficulty of knowledge transmission and understanding and the fact that misinterpretation of social situations may cause conflicts, an unsuitable style for the audience, and so on (Van Dijk, 2002, p. 217). The other areas where the majority was on the same page are evident in terms of the structures of sentences and length of the speech. In other words, most of the participants agree on the importance of short, comprehensible words and active sentences and relatively short speeches of 15 to 20 minutes.

As a matter of fact, differences do appear on the main issues, in particular persuasion and the characteristic features of an introduction, body, and conclusion as well as the speechwriter-speaker relationship. The varied answers received from participants regarding persuasion, from sentence structure to speaker's character, indicate that this depends on the combination of all aspects of a speech, such as logic, emotion, evidence, the speaker's credibility, and simplicity. Another difference was identified regarding the features of the introduction, body, and conclusion of a speech. Some participants evaluate the speech as a whole, others assert that the introduction should be short, effective, and alluring, the body should be designed around the key message and enriched with both emotions and logic, and the conclusion should call for an action or idea. As to the last point, the speechwriter-speaker relationship is not at a certain level, as it may change from person to person, so the participants categorize their relationships within the scope of business/professionalism, sincere/warm or variable. But it must be said that speechwriters should know the speakers they work with as much as possible to understand their expectations and character.

Last but not least, to reach a wider audience, traditional media and social media should be considered while writing a speech. The points gathered from participants in terms of gaining media attention can be described as short, striking statements, sound bites, famous quotes, and interesting ideas. From the perspective of social media, it constitutes both an advantage and a risk for speeches. The participants consider it an advantage due to the fast transmission of speeches while there is also a risk in terms of the spread of misinformation at the same speed and to the same masses. Aside from social media's power for speeches, it cannot be a replacement for the emotional interaction established face-to-face with the audience. 


\section{ENDNOTES}

1. This study is revised version of summary of an MA thesis titled: Executive Writing in Point of Public Relations: An Applied Study on Speechwriting. Only the study abstract was published in conference proceedings in 2016/Malaysia and rewritten for publication.

2. The information about speechwriters (participants of the research) and the executives they worked with was gathered in 2015-2016. There could be changes in speechwriters' jobs and leaders'/executives' positions at the present time.

3. As a rhetorical device the Rule of Three: When the points that need emphasis are listed in three, this creates a sense of completeness and illusion of finality. Because people are accustomed to hearing views/arguments in twos (e.g. right-left, blackwhite, up-down), when a third is added, it feels like hammering the last nail (e.g. ready, steady, go) (Lancaster (2010, p. 32).

4. David Murray is not a speechwriter, but he brings speechwriters together in conferences and online platforms by virtue of being the director of the Professional Speechwriters Association. He contributed his observations on speechwriters to the research.

Peer-review: Externally peer-reviewed.

Conflict of Interest: The author has no conflict of interest to declare.

Grant Support: The author declared that this study has received no financial support.

\section{REFERENCES}

Aristoteles, (2014). Retorik. İstanbul, Turkey: Yapı Kredi Yayınları.

Aristotle (2004). The art of rhetoric. (H. Lawson-Tancred, Trans.). London, UK: Penguin Books.

Bivins, T. H. (1999). Public relations writing the essentials of style and format. Lincolnwood, IL, United States of America: National Textbook Company.

Bradley, B. E. (1975). Fundamentals of speech communication: The credibility of ideas. United States of America: Wm. C. Brown Company Publishers.

Booth, W. C. (2004). The rhetoric of rhetoric. A quest for effective communication. Oxford, UK: Blackwell Publishing. Burgoon, M. (1974). Approaching speech/communication. United States of America: Holt, Rinehart and Winston.

Collins, (2005). Public speaking. Conquer your nerves and make a great impression. Glasgow: HarperCollins Publisher.

Coombs, T.W. (2009). Crisis, crisis communication, reputation, and rhetoric. In Robert L. Heath, Elizabeth L. T. \& Damion W. (Eds.), Rhetorical and critical approaches to public relations II (pp. 237-252). New York, USA: The Taylor \& Francis. 
Erdoğan, İ. (2012). Pozitivist metodoloji ve ötesi. Ankara, Turkey: Erk Yayınları.

Glover, D. (2011). The art of great speeches and why we remember them. New York, USA: Cambridge University Press. Geray, H. (2006). Toplumsal araştırmalarda nicel ve nitel yöntemlere giriş. Ankara, Turkey: Siyasal Kitabevi.

Kjeldsen, J. E., Kiewe, A., Lund, M. \& Hansen, J. B. (2019). Speechwriting in theory and practice. Cham: Palgrave Macmillan.

Lancaster, S. (2010). Speechwriting. London, UK: Robert Hale.

Leith, S. (2011). You talkin' to me? Rhetoric from Aristotle to Obama. Great Britain: Profile Books.

Lukaszewski, J. E. (1992). Influencing public attitudes: Direct communication strategies that reduce the media's influence on public decision making. United States of America: Action Publications.

Luntz, F. (2007). Words that work. United States of America: Hyperion.

Meho, L. I. (2006). Email interviewing in qualitative research: A methodological discussion. Journal of the American Society for Information Science and Technology. 57(10), 1284-1295.

Meyer, M. (2009). Retorik (I. Yerguz, Trans.). Ankara, Turkey: Dost Kitabevi Yayınları.

Medhurst, M. J. (2003). Enduring Isuues in Presidential Speechwriting. In Ritter, Kurt \& Medhurst, Martin J. (Eds.), Presidential speechwriting. United States of America: Texas A\&M University Press.

Morton, R. K. (1968). Public relations writing and the corporate image. Journal of Business Communication, 5(2), 31-37.

Muallimoğlu, N. (2011). Hitabet konuşma sanatı. İstanbul, Turkey: Avcıol Yayıncılık.

Newsom, D. \& Haynes, J. (2008). Public relations writing form and style. United States of America: Thomson Wadsworth.

Osborn, M. \& Osborn, S. (2000). Public speaking. Newyork: Houghton Mifflin.

Patton, M. Q. (2002). Qualitative reserach and evaluation methods. United States of America: Sage Publications.

Seidman, I. (2006). Interviewing as qualitative research: A guide for researchers in education and the social sciences. New York, USA: Teachers College Press.

Steward, H. D. (2005). Good writing is good public relations. Public Relations Quarterly, 50(4), 41-45.

Tekin, H. H. (2012). Nitel araştırma yönteminin bir veri toplama tekniği olarak derinlemesine görüşme. Sosyoloji Dergisi. 3(13), 101-116.

Tepebaşılı F. (2016). Retorik konuşma sanatı - Söz bilimi. Konya, Turkey: Çizgi Yayıncılık.

Van Dijk, T. A. (2008). Discourse and context: A sociocognitive approach. UK: Cambridge University Press.

Van Dijk, T. A. (2002). Political discourse and political cognition. In P. Chilton \& P. Schaffner (Eds.), Politics as text and talk: Analytical approaches to political discourse (pp. 204-236). Netherlands: Benjamins.

Wallace, R. (2020). Ethics in political speechwriting. In Peter Loge (Ed.), Political communication ethics: theory and practice (pp. 207-219). Lanham: Rowman \& Littlefield. 


\section{TABLES}

Table 1: Research Participants and Their Career History

\begin{tabular}{|c|c|c|}
\hline Speechwriters Name/Surname & Countries & Experiences \\
\hline Speechwriter 1 & Germany & $\begin{array}{l}\text { She has been writing speeches for almost } \\
\text { eight years. She started speechwriting in } \\
\text { a small German PR agency specializing in } \\
\text { speechwriting. Currently, she is writing } \\
\text { speeches for Members of the Managing Board } \\
\text { of Siemens AG. }\end{array}$ \\
\hline Speechwriter 2 & Canada & $\begin{array}{l}\text { He is a Canadian speechwriter and speech- } \\
\text { writing coach who writes executive-level } \\
\text { speeches for leaders throughout the world. } \\
\text { Before launching his business, Global Speech- } \\
\text { writer, he worked for more than a decade } \\
\text { writing speeches for the most senior levels of } \\
\text { the Canadian government and members of } \\
\text { the United Nations. }\end{array}$ \\
\hline Speechwriter 3 & United Kingdom & $\begin{array}{l}\text { He has been writing speeches for twenty } \\
\text { years. He first started in the Toastmasters } \\
\text { International organization. He is a founder } \\
\text { of the European Speechwriters Network. His } \\
\text { first professional work was for BP, and he later } \\
\text { worked writing speeches for weddings and } \\
\text { birthdays. }\end{array}$ \\
\hline Speechwriter 4 & Turkey & $\begin{array}{l}\text { She has been writing speeches for ten } \\
\text { years in various corporate communication } \\
\text { departments, besides other duties. She writes } \\
\text { speeches for the CEO of Siemens Turkey. }\end{array}$ \\
\hline Speechwriter 5 & $\begin{array}{l}\text { United States of } \\
\text { America }\end{array}$ & $\begin{array}{l}\text { He founded the White House Writers Group } \\
\text { and was the speechwriter for US Vice Pres- } \\
\text { ident George H.W. Bush (1984-1986) and } \\
\text { President Ronald Reagan (1986-1989). He still } \\
\text { writes speeches for business leaders. }\end{array}$ \\
\hline Speechwriter 6 & The Netherlands & $\begin{array}{l}\text { She wrote speeches for the Dutch Ministry of } \\
\text { Economic Affairs for four years and headed } \\
\text { the speechwriting department. Since 2003, } \\
\text { she has been running her own company, } \\
\text { "Speechless" which offers personal speech } \\
\text { coaching programs. She also trains speech- } \\
\text { writers. }\end{array}$ \\
\hline
\end{tabular}




\begin{tabular}{|c|c|c|}
\hline Speechwriter 7 & Turkey & $\begin{array}{l}\text { He wrote speeches for the former Chairman of } \\
\text { the Executive Board of Turkish Airlines, Hamdi } \\
\text { Topçu, and Turkish Airlines CEO Temel Kotil. }\end{array}$ \\
\hline Speechwriter 8 & Turkey & $\begin{array}{l}\text { He was a journalist for ten years beginning in } \\
\text { 1987, and he started to work as a speechwrit- } \\
\text { er in the Turkish Prime Ministry in 1997. He } \\
\text { currently writes texts as the Chief Advisor of } \\
\text { the President of the Republic of Turkey, H.E. } \\
\text { Recep Tayyip Erdoğan. In addition, he has } \\
\text { been a lecturer in Gazi University's Faculty of } \\
\text { Communication since } 1999 .\end{array}$ \\
\hline Speechwriter 9 & United Kingdom & $\begin{array}{l}\text { He is a speechwriter, speechwriter trainer, } \\
\text { occasional contributor to the Guardian, } \\
\text { cartoonist, and co-director of the communica- } \\
\text { tions consultancy CreativityWorks Ltd. }\end{array}$ \\
\hline Speechwriter 10 & Turkey & $\begin{array}{l}\text { He wrote speeches for the President of the } \\
\text { Republic of Turkey, H.E. Recep Tayyip Erdoğan, } \\
\text { for ten years and is a writer / Chief Advisor for } \\
\text { the Turkish government. }\end{array}$ \\
\hline Speechwriter 11 & Nigeria & $\begin{array}{l}\text { He is a Corporate Communications Arrow- } \\
\text { head, a Brand Strategist, a Certified Nego- } \\
\text { tiation Specialist and Innovation Catalyst } \\
\text { from the Global Innovation Management } \\
\text { Institute. He was the Chief Speechwriter to } \\
\text { the President/Chairman of Council of the } \\
\text { Certified Pension Institute of Nigeria for two } \\
\text { years, where he crafted speeches for numer- } \\
\text { ous functions for the president and has since } \\
\text { written speeches for high-profile executives } \\
\text { of corporation and government spaces. He is } \\
\text { also a writer of distinction with diverse writing } \\
\text { platforms. }\end{array}$ \\
\hline Speechwriter 12 & Scotland & $\begin{array}{l}\text { He is an award-winning speechwriter who } \\
\text { has been writing speeches since } 2002 \text {. He } \\
\text { currently writes for the Convener of the } \\
\text { Scottish Parliament's Economy, Energy \& } \\
\text { Tourism Committee, having previously written } \\
\text { for a plethora of members of the Scottish } \\
\text { Parliament. In addition, he has written arts } \\
\text { journalism, essays, stories, and poetry. }\end{array}$ \\
\hline
\end{tabular}




\begin{tabular}{|c|c|c|}
\hline Speechwriter 13 & Denmark & $\begin{array}{l}\text { He is an award-wining independent Speech- } \\
\text { writer (formerly for the Danish Ministries for } \\
\text { Climate, Energy and Building, and Environ- } \\
\text { ment). }\end{array}$ \\
\hline Speechwriter 14 & United Kingdom & $\begin{array}{l}\text { He is a leading international speechwriter. He } \\
\text { has written speeches for senior executives at } \\
\text { IBM, Ford, Du Pont, Toshiba, Ford, and Shell. } \\
\text { He has appeared on TV and in print as a } \\
\text { speech analyst and commentator. He is also a } \\
\text { published novelist. He started as a profession- } \\
\text { al writer working in scripts for documentary } \\
\text { films and won awards at the New York and Bi- } \\
\text { arritz film festivals. He is the founder of World } \\
\text { Speech Day, which had its inaugural year on } \\
\text { March } 15 \text { th, } 2016 \text { and featured some } 200 \text { live } \\
\text { speaking events in thirty nations across the } \\
\text { globe. He has been writing speeches for over } \\
\text { twenty years. }\end{array}$ \\
\hline Speechwriter 15 & Turkey & $\begin{array}{l}\text { He has been a political consultant and } \\
\text { speechwriter for five years. He wrote speeches } \\
\text { for Tuğrul Türkeş between } 2011 \text { and } 2015 \text {. }\end{array}$ \\
\hline Speechwriter 16 & $\begin{array}{l}\text { United States of } \\
\text { America }\end{array}$ & $\begin{array}{l}\text { He is the senior speechwriter for the National } \\
\text { Education Association's Top Executives. He } \\
\text { has been writing speeches for twelve years. } \\
\text { He worked as a freelance speechwriter for } \\
\text { individuals and political candidates. }\end{array}$ \\
\hline Speechwriter 17 & Tanzania & $\begin{array}{l}\text { He is the previous Private Secretary and } \\
\text { speechwriter to the Minister for Foreign Af- } \\
\text { fairs and International Cooperation of Tanza- } \\
\text { nia, Speechwriter to the President of Tanzania, } \\
\text { H.E. Jakaya Mrisho Kikwete, and is currently } \\
\text { Private Secretary and speechwriter for Former } \\
\text { President Jakaya Mrisho Kikwete. }\end{array}$ \\
\hline Speechwriter 18 & Canada & $\begin{array}{l}\text { Over the past } 25 \text { years, as president of her } \\
\text { own communication company, she has } \\
\text { written speeches for government ministers } \\
\text { and executives as well as for executives in } \\
\text { business and the non-profit sector. }\end{array}$ \\
\hline Speechwriter 19 & Germany & $\begin{array}{l}\text { He is a co-founder of the German Speechwrit- } \\
\text { ers Association (VRdS) and was speechwriter } \\
\text { to the CEO of Lufthansa. He has been writing } \\
\text { speeches for } 25 \text { years. }\end{array}$ \\
\hline
\end{tabular}




\begin{tabular}{|l|l|l|}
\hline Speechwriter 20 & $\begin{array}{l}\text { United States of } \\
\text { America }\end{array}$ & $\begin{array}{l}\text { He is Leadership Communications Director } \\
\text { at the Coca-Cola Company and has written } \\
\text { speeches for the President of Coca-Cola Re- } \\
\text { freshments, President of the largest Coca-Cola } \\
\text { bottler, the President of the Coca-Cola North } \\
\text { America Group, the Chairman and CEO of } \\
\text { UPS, the Chairman and CEO of Havertys Furni- } \\
\text { ture, and the President of the Federal Reserve } \\
\text { Bank of Atlanta, among others. }\end{array}$ \\
\hline Contributor 1 & $\begin{array}{l}\text { He is the owner of Pro Rhetoric, LLC, which } \\
\text { publishes Vital Speeches of the Day Maga- } \\
\text { zine and oversees the Cicero Speechwriting } \\
\text { Awards. He is the executive director of the } \\
\text { Professional Speechwriters Association. }\end{array}$ \\
\hline
\end{tabular}

